\title{
Escolástica e praxismo na teoria do direito de João Mendes Júnior.
}

\author{
Miguel Reale \\ Presidente do Instituto Brnsileiro de Filosofia - \\ Catedrático de Filosofia do Direito na Faculdade de \\ Direito da Universidade de São Paulo
}

\section{Sua posição filosófica}

1 - Há escritores cuja situação no mundo da Filosofia fàcilmente se configura, não só pela substância mesma de suas idéias, como pelas profissões de fé que sentem a necessidade de ir fazendo, reiteradas vêzes, ao longo de sua atividade intelectual.

Tais posições podem tornar-se ainda mais pronunciadas e definidas quando adquirem certo sentido polêmico, máxime quando se defrontam portadores de idéias novas com corajosos defensores das doutrinas tradicionais. Foi o que se deu no fim do século passado e no início dêste, na Faculdade de Direito de São Paulo, ao travar-se um diálogo, marcado por vivacidade sem acritude, entre João Mendes Júnior, o escolástico, e os adeptos da Filosofia positiva, com Pedro Lessa à frente.

Bem nítida, por certo, a distinção dos dois campos, os mesmos que então dividiam a intelectualidade brasileira, situando-se em plano distinto apenas a obra de Farias Brito, como uma voz de transição, prenunciadora de algumas das questões mais palpitantes do pensamento contemporâneo. Esta missão singular desempenhada pelo autor da Finalidade do mundo só pode ser contestada por manifesto espírito sectário, quaisquer que possam ser as restrições 
cabíveis à sua doutrina, nem sempre liberta de influências oriundas dos sistemas criticados.

Numa atmosfera carregada de positivismo e de naturalismo spenceriano, João Mendes Júnior mantém-se a vida inteira fiel à linha tradicional da Escola, com a fé e o entusiasmo mais próprios dos que se julgam na vanguarda inovadora dos princípios. A originalidade não o seduz; tem receio do novo ou do imprevisto, dos estudos "sombreados pela preocupação da novidade", consoante a frase de restrição crítica por êle empregada ao analisar a Teoria do Processo Civil e Comercial de João Monteiro (1).

Por mais fidelidade que se tenha a uma doutrina, pode acontecer, todavia, que os debates acabem influindo no espírito dos contendores: certas idéias vão lenta e imperceptivelmente se insinuando no campo adverso, ocultando-se nas dobras de uma terminologia alheia, mal ajustada a princípios e a inspirações desconformes. Nem falta a hipótese extrema e paradoxal de uma troca inadvertida de posições quanto a êste ou àquele outro ponto da polêmica, como se assistisse razão a Soren Kierkegaard ao lembrar-nos, com finura, a ambivalência do ser humano "que é continuamente o seu contrário".

Focalizando as divergências que separavam os dois grandes mestres de nossa Faculdade, não seria desarrazoado perquirir o alcance da influência porventura exercida pelo tradicionalismo de João Mendes Júnior sôbre as teorias de Pedro Lessa, que admitia, embora a seu modo, a validade de uma lei natural do Direito, assim como via na Metafísica "um conjunto de especulações sôbre os seres e os fenômenos, que não podemos conhecer cientificamente", e que "só o acanhado e vesgo espirito de seita repele" (2).

(1) V Rev. da Fac. de Direito de São Paulo, vol. VII, 1899, pág. 34. Nas notas sucessivas farei referência a esta publicação, indicando o volume, o ano e a página, da seguinte forma: Rev., VII, 1899/34.

(2) Rev., IV, 1897/13. 
Da mesma forma, não é de se excluir o impacto da então chamada "Filosofia científica" sôbre o modo de pensar de João Mendes Júnior, não só o atraindo para a meditação de seus coevos, como atenuando os exageros de seu racionalismo abstrato, às vêzes desligado do real e do concreto.

São considerações que me acodem logo no início destas notas de estudo, destinadas à análise dos pressupostos fiIosóficos que condicionaram a obra de um jurisconsulto, para quem a especulação filosófica não foi algo de ocasional ou de periférico, mas se inseriu poderosamente no cerne de sua vigorosa contribuição às letras jurídicas pátrias. É, pois, "sine ira ac studio", antes com objetividade e simpatia, que me proponho acercar-me dos trabalhos de João Mendes Júnior, visando situá-lo nos quadros do pensamento jurídico nacional, procurando não ser influído por imagens ou clichês consagrados.

2 -- No caso do antigo professor de Prática Forense e de Teoria e Prática do Processo Civil, Comercial e Criminal, não se pode, em verdade, asseverar que seja infiel a imagem que a tradição nos of erece de um defensor ardoroso e intemerato da Escolástica, mais correspondente ao seu temperamento severo, pouco dado a originalidades e. a cortes críticos no processo da cultura, mas é necessário precisar melhor o sentido de sua participação no movimento geral de renovação do tomismo operado a partir de meados da passada centúria. (3)

Por outro lado, além do problema central de sua caracterização como "escolástico" ou "neo-escolástico (expressões que não são evidentemente sinônimas) é mister indagar de outras fontes inspiradoras de seu pensamento, pertinentes à cultura jurídica, desde os praxistas lusos, aos

(3) Para uma explanação da doutrina de João Mendes Júnior segundo o prisma "aristotélico-tomista", v. Manuel Carlos de Figueiredo Ferraz - Apontamentos sôbre a nução ontológica do processo. São Paulo, e o estudo de Ester de Figueiredo Ferraz $A$ orientação filosófica de João Mendes Júnior, em "Ensáios de Filosofia do Direito”, São Paulo, 1952, págs. 12 usque 55. 
quais êle devota admiração carinhosa e constante, até Jhering e a outros juristas de seu tempo.

Cabe desde logo observar que até mesmo historiadores de formação tomista, como o Padre Leonel Franca, a.o analisarem a obra dos escolásticos no Brasil, omitem o nome de João Mendes Júnior, apesar de merecerem referência autores de menor significação no desenvolvimento de nossas idéias (4), o que talvez se explique por não ter êle publicado uma obra específica de Filosofia, salvo as páginas de seus Elementos de Psicologia e de Lógica, com uma "Sinopse da história da Filosofia"

Quem, no entanto, entra em contato com os trabalhos jurídicos de João Mendes Júnior, não pode deixar de se surpreender com uma preocupação bem rara entre os cultores de Jurisprudência, qual seja a de buscar sempre os่ pressupostos fillosóficos dos institutos e dos sistemas. À luz dessas páginas, que não são esporádicas, mas constituem parte essencial da obra do jurista, e à vista da influência exercida sôbre colegas e discípulos, até nossos dias, não será exagero afirmar que foi o nosso mestre de Direito Judiciário a figura mais representativa da Escolástica em São Paulo nas três primeiras décadas do regime republicano.

3 - Desnecessário é rememorar aqui o que foi o surto do pensamento tomista na segunda metade do século XIX, desde a atividade do grupo da "Civiltà Cattolica" e os esforços decisivos de Taparelli d'Azeglio, Liberatore, Sanseverino e Kleutgen até os aplausos da Encíclica "Aeterni Patris" do papa Leão XIII (1879), irradiando-se com redobrado sucesso através de Lovaina, Paris, Milão ou Friburgo.

(4) V. Leonel Franca - Noções de história da Filosofia, 8. ${ }^{a}$ ed., Rio, 1940, págs. 301 e segs.

(5) Edição póstuma, com prefácio de Reynaldo Pochat, São Paulo, 1937. Trata-se de lições organizadas para seu filho, João Mendes Neto, quarro êste se praparava, em 1914, para os exames de admissão à Faculdade de Direito. A sinopse de História da Filosofia é uma conferência proferida em 1916. 
Pois bem, êste movimento teve no Brasil dois lídimos representantes no mundo da Jurisprudência: José Soriano de Souza no Norte, e João Mendes de Almeida Júnior no Sul; o primeiro se defrontando com a pena sarcástica de Tobias Barreto e Silvio Romero; o segundo, em fase posterior e em ambiente menos propício a paixões filosóficas, se deparando com os positivistas heterodoxos e os evolucionistas de Piratininga.

Se, no entanto, Soriano de Sousa escolheu com acêrto, no dizer de Leonel França, "entre os escolásticos modernos os que melhor interpretaram o pensamento antigo e mais contribuiram para a sua rehabilitação" (6) o nosso João Mendes Júnior preferiu a Escolástica ibérica do século XVI, muito embora revelasse conhecer a obra dos renovadores do tomismo e fôsse afeito ao estudo direto dos textos de Santo Tomás. (7)

Não é demais, a esta altura, relembrar que a história do pensamento filosófico no Brasil, até época bem recente, não pode ser feita à margem das Faculdades de Direito de São Paulo ou do Recife, não só por terem sido os dois focos irradiadores por excelência das idéias universais no País, como pelo significado intrínseco do que nelas se ensinava. No que se refere à formação e ao desenvolvimento das idéias no Brasil, constitui lacuna inexplicável a de fazer-se abstração do diálogo ou da polêmica travados entre os escolásticos e os adeptos da chamada Filosofia cientí-

(6) Op. cit., pág. 303.

(7) João Mendes Júnior comprazia-se em invocar ensinamentos de Henrique de Gand, o doctor solemnis, a-propósito da "causa material"; de Francisco Mayronis, o doctor illuminatus, quanto à "causa formal", etc., (o que suscitou a crítica irônica de Pedro Lessa, Rev. VII, 1899/132, sôbre os "abantesmas da Filosofia medieval”) mas fazia questão de ponderar deverem todos ser lidos com a correção do doctor angelicus... (v. Rev., I, 1893/117, n. 1 e 122, n. ${ }^{\circ}$ 2). 
fica, e que dividiam, às vêzes violentamente, os catedráticos de Direito. (8)

4 - A posição filosófica de João Mendes Júnior, como acima foì dito, corresponde cronològicamente à chamada geração intermédia da neo-Escolástica, isto é, à geração situada entre a dos iníciadores da renovação e a de nossos dias, - esta mais dedicada ao fundo do que às roupagens verbais do pensamento tomista, e dotada de incontestável vigor metafísico, com mais apurado senso histórico, como o demonstram os estudos de Gilson, Maritain, Sertillanges, Olgiati, Grabmann, etc. Espiritualmente, porém a situação de nosso jurisconsulto talvez se caracterize melhor como derivação tardia da Escolástica hispano-portuguêsa da Contra Reforma.

Os progressos do tomismo na segunda metade do século XIX, conseguindo reconquistar um lugar de relevo no diálogo universal das idéias, após o seu quase eclípse nos horizontes da cultura moderna; a revisão de vários princípios superados pela crítica de Descartes, Kant e seus continuadores; uma preocupação maior pelos problemas da ciência; o abandono de sua antiga terminologia, pouco correspondente às formas de sentir e de pensar do homem contemporâneo, tudo, em suma, que pode representar algo de novo e capaz de distinguir o neo-tomismo (visto como

(8) Pedro Lessa manifestava plena consciência dêsse problema, em palavras mais atuais do que nunca: "Apague-se a história das academias jurídicas do Brasil, e a história da nação brasileira será um enígma. Entretanto, em tôrno dessas duas academias tem-se ouvido, nos últimos tempos, um surdo rumor de vozes adversas, que não poucas vêzes se alteiam até se converterem em formais increpações e ameaças de extermínio" - Rev., 1896/331. Só o tolo preconceito contra as Faculdades de Direito, tão inconsistente e frágil como o de atribuir-se ao "bacharelismo" a responsabilidade por tôdos os males nacionais, só um estrabismo cultural dessa ordem explica o silêncio reiterado ou a meia compreensão de certos círculos sôbre tudo quanto provenha de jurisconsultos como Joâo Mendes Júnior, Pedro Lessa, Clovis Bevilaqua, ou Lafayette Rodrigues Pereira. 
êste não abandona as teses centrais de Santo Tomás) atua no espírito do mestre João Mendes Júnior como fermento de entusiasmo e de confiança na posição assumida, como o combatente que peleja com mais ardor ao saber da existência de.aliados travando a mesma batalha. Não nos iludamos, porém: as suas convicções permanecem imutáveis, ainda e sempre fiéis à linha aristotélico-tomista tradicional, continuando a preferir até mesmo a técnica expressional dos doutôres antigos, que pode ter virtudes de precisão, mas sôa rudemente aos nossos ouvidos. (9)

Não se pense, com ef eito, que êle estivesse identificado, no fundo e na forma, com os mestres cujo nome invocava cheio de júbilo e de confiança, contrapondo a fôrça do tomismo às pretensões da Filosofia positiva. Tal entusiasmo não afetava o seu apêgo à linguagem tradicional da Escolástica, que êle se habituara a admirar nos textos dos praxistas.

5 - ̀̀ primeira vista pode parecer que João Mendes Júnior se enfileire entre os neo-tomistas, como acontece na famosa polêmica com Pedro Lessa, ao lembrar os nomes de Saint Hilaire, Liberatore, Sanseverino, Broglie, etc., para proclamar, com insólita vibração:

"Em suma, as obras modernas, em geral, vão buscar no Filosófo (sic) as primeiras noções e no Anjo da Escola (sic) as definições: Carrara vai buscar na Escola o seu método ontológico para a análise do crime; Puglia, apesar de todo o seu positivismo, empenhado em definir o crime,

(9) “O latim dos filósofos do século XIII não tem pretensões literárias, escreve Maurice de Wulf. Tôdos sacrificam a forma à idéia. Porém, a sua terminologia técnica é precisa. Nos grandes escolásticos, a lingua possui claridade e vigor" (História de la Filosofia Medieval, trad. cast., México, 1945, vol. II, pág. 19). Depois do século XV generalizou-se, no entanto, o emprêgo de uma série de expressões esteriotipadas, a que João Mendes paga pesado tributo. 
recorre, não a Francisco Bacon, mas a Santo Tomás de Aquino. Enfim, a Escolástica será a Filosofia do século XX". (10).

Não é, porém, com menor entusiasmo que assevera:

"Por fim, observe o ilustre professor a Escola a que pertenceram Heinecio, Vinnio, Strykio e Boehmero, e a que se filiaram praxistas reinícolas e os nossos mais notáveis jurisconsultos pátrios: Morais dividiu o exame das nulidades dos contratos e dos instrumentos em quatro partes, tendo em vista as causas material, eficiente, formal e final, conforme a classificação da Escola; Guerreiro escreveu um tratado de Ética escolástica, sob o título Escola Moral; Mendes a Castro, Gomes, Vanvergue, a cada passo, se referem à Escola e à sua terminologia; Melo Freire, Pereira e Souza e o próprio Almeida e Souza eram escolásticos; o nosso saudoso Teixeira de Freitas, na sua monumental introdução à Consolidação das Leis Civis, deixou, na técnica que emprega, o cunho da mais rigorosa subordinação ao método escolástico; os nossos jurisconsultos são, em geral, escolásticos, sem que ficassem acobardados por aquela nota dos Estatutos de Coimbra, pela qual o poderoso ministro Pombal denominava a Escolástica - Filosofia dos árabes". (11)

É na esteira dos praxistas que o nosso Autor aplica as noções da Lógica aristotélica, nos moldes da Escolástica, não só nos seus trabalhos de Prática Forense, - cujo, programa é dividido em quatro partes, segundo as quatro causas da atividade forense, considerando-se, outrossim, a matéria ex qua, circa quam et in qua; a causa formal ut

(10) Rev., VII, 1899/155.

(11) Rev., VII, 1899/155. Quanto a Teixeira de Freitas, pelo menos, parece-me discutível a afirmação de João Mendes Júnior. Cf. infra, n. 21. Já em 1893, João Mendes Júnior se referira ao escolasticismo dos praxistas, notadamente a Moraes, no de execut., L. II, cap. XVIII, n. ${ }^{\circ}$ 25, em relação aos contratos. V. Rev., I, $1893 / 116$, nota 1 . 
species, ut exemplar, etc (12) - como em seu Direito Judiciário Brasileiro, no qual a mesma orientação prevalece, notadamente quanto à análise do processo sob o prisma da velha noção escolástica de "movimento". (13)

Por aí se vê que a aplicação de ensinamentos escolásticos na concepção do Direito Processual não constitui uma inovação de João Mendes Júnior, mas antes a continuação de uma tendência dominante no direito reinol, a que êle concientemente se filia, chegando a determinações conceituais e terminológicas a que os especialistas não têm regateado louvores.

\section{O “aristotelismo” de João Mendes Júnior}

6. No ensáio sôbre a orientação filosófica do jurista, cujo centenário se comemorou em 1956, Ester de Figueiredo Ferraz lembra que, de tôdas as disciplinas filosóficas, a que mais atraiu o seu espírito foi a Lógica, explicando-se tal predileção por ser a que melhor se presta ao papel de ciência auxiliar da Dogmática Jurídica. A Filosofia teria sido, para êle, pirncipalmente uma "ancilla Jurisprudentiae":

"Em atenção à Jurisprudência estudou com carinho a Filosofia. Ter-se-ia dedicado, com igual fervor, à matemática e às ciências físicas ou naturais, se tais disciplinas fôssem indispensáveis ao melhor conhecimento do Direito.

"E é por isso, porque a Filosofia, para João Mendes, representou mais um instrumento útil à construção de sua obra jurídica, que não exerceu o grande processualista in-

(12) Rev., IV. 1896/251 usque 289. Êste "programa de ensino" é bem característico da "forma mentis" de nosso autor, revelando a influência concomitante da Escolástica e dos praxistas.

(13) Direito Judiciário Brasileiro, Rio-São Paulo, 1940, 3.a edição págs. 227 e segs. A primeira é de 1918. 
fluência decisiva sôbre o pensamento filosófico de sua época". (14)

Não me parece, todavia, seja bem esta ou só esta a razão da preferência de João Mendes Júnior pelas cogitações lógicas. Talvez o problema possua raizes mais profundas, ligando-se ao cunho de "praticidade" ou de "instrumentalidade pragmática" que, em geral, assinala o pensamento luso, onde o Orgánon de Aristóteles não raro prima sôbre a Summa de Santo Tomás.

É irrecusável a predileção natural de seu espírito pelos grandes problemas da Lógica e da Dialética, o que explica o seu menor interêsse pelos ensinamentos da Ética a Nocômaco, ou pelas páginas da Summa dedicadas às questões de ordem moral. Também os grandes lógicos modernos e contemporâneos o atraem, como o demonstram os resumos e notas especiais dedicados a Bacon e a Stuart Mill na já lembrada Sinopse da história da Filosofia.

Por outro lado, não será demais focalizar o sentido do "aristotelismo" de João Mendes Júnior, enquadrando-o na evolução do pensamento português e brasileiro.

Analisando, com olhos desembaraçados de preconceitos perturbadores, o panorama da nossa cultura, parece-me possivel extender, em parte, ao Brasil a tese de Cabral de Moncada sôbre o valor dominante da Escolástica em sua terra, como uma espécie de "constante" ou de "núcleo resistente" na linha entrecortada das múltiplas influências recebidas. Tal reconhecimento deve ser feito objetivamente, muito embora possam variar os critérios de sua estimativa, pois, se não falta quem enalteça tal fato, outros o consideram a causa essencial da insignificância dos luso-brasileiros no concêrto da Filosofia ocidental.

Diz o citado mestre de Coimbra, focalizando a questão do ponto de vista da Filosofia Júrídica, que todos os mo-

(14) Ensáio cit., pág. 54. Como veremos, a influência de João Mendes Jr. foi bem grande entre os juristas da geração posterior. 
vimentos de idéias ocorridos em Portugal, desde o racionalismo iluminista até ao krausismo e ao positivismo, apontavam, afinal, "com balas diferentes, ao mesmo alvo: o escolasticismo de nossa mentalidade histórica e misoneista, sempre pouco propensa a abraçar novidades nos domínios do pensamento filosófico". (15)

É a razão pela qual, acrescenta Moncada, algumas doutrinas modernas, "perdida uma boa parte da sua virulência ao transpor a fronteira, tinham acabado por envergar, ao fim de algum tempo, uma veste escolástica"

"Sempre e em todos os momentos que se seguiram às mais violentas crises de nossa cultura nacional, o espírito escolástico tinha acabado por se instalar na raiz do pensamento português". (16)

Pode-se dizer que no Brasil as coisas se passaram mais brandamente, pois tempo houve em que os nossos escolásticos, falhos de conhecimento mais profundo da doutrina tomista, deixaram o campo livre aos espiritualistas ecléticos, primeiro, e aos positivistas e evolucionistas, depois. Não é menos certo, porém, que, quando se operou a reação contra o naturalismo do século XIX, após a experiência singular de Raimundo de Farias Brito, e quase como derivação de seus ensinamentos, o que tivemos foi um renascimento da Escolástica, enquanto que, na Europa, a crítica ao positivismo abria perspectivas às teorias mais vivas do pensamento contemporâneo, como às do neo-kantianos, neo-hegelianos, bergsonianos, etc. Em suma, até época bem recente, não será exagero afirmar que, no diálogo ou na polêmica das idéias, a Escolástica tem sido, no mais das vêzes, "o outro interlocutor", com maior ou menor brilho, mas sempre representativo de uma constante no pensamento nacional.

(15) Cabral de Moncada, Subsídios para uma História da Filosofia do Direito em Portugal, 2. a ed., Coimbra, 1938, pág. 142.

(16) Op. cit., pág. 143. 
Escolasticismo e anti-escolaticismo em um contraste permanente, revesando-se apenas os adversários da Escolástica sob a inspiração de múltiplas doutrinas. Daí as soluções ecléticas, as composições e as justaposições ditadas por necessidades práticas imediatas, ou por certa tendência para fugir das tensões espirituais violentas ou duradouras. No que se refere aos domínios jurídicos, por exemplo, êsse ecletismo conciliador, nascido de um fundo desejo de composição harmônica ou vistosa, revela-se nos nossos seguidores do espiritualismo de Cousin, nos jusnaturalistas inspirados en Krause, no jusnaturalismo ajustado à doutrina de Kant, como no caso do Conselheiro Lafayette, e até mesmo no setor positivista, como é exemplo Pedro Lessa.

Os momentos de franco e aberto contraste com a Escolástica têm sido mais de críticas externas e de virulência verbal do que de clara e positiva conciência de seu "superamento", não atingido por certo por Tobias Barreto ou Sílvio Romero, pois só poderá ser o fruto da meditação serena das exigências históricas, sociais e espirituais que determinaram o persistir de sua poderosa influência em Portugal e no Brasil.

Postos assim os dados da questão, adquire outro sentido, de mais densidade especulativa, a tese tantas vêzzes repetida, e afinal não destituída de fundamento, sôbre o caráter prático, realista ou pragmático da cultura portuguêsa (17) pois há também escolásticos de olhos abertos para as exigências práticas, como tôda a obra de João Mendes Júnior o demonstra.

(17) Entre nós é João Cruz Costa quem tem sabido justificar melhor a doutrina sôbre ser a cultura portuguêsa fundada na valorização pragmática da existência: "Desde a Idade Média é fácil verificar no pensamento português a constância de uma posição empírica, pragmática" (Cf. Contribuição à história das idéias no Brasil, Rio, 1956, págs. 31 e segs.)

Há no Brasil, por efeito talvez da "herança portuguêsa", uma forte tendência para servirmo-nos das idéias como instrumentos 
Além disso, a constância do diálogo acima apontado explica a coexistência paradoxal de dois ingredientes de nossa cultura: o misoneismo, ou seja, o apêgo às formulas consagradas e a aversão sistemática por tudo que seja novo; e o filoneismo, a tentação da novidade, a inclinação para o que se considera a "última e mais perfeita verdade". Mas como o "novo" já nos chega às vêzes desvitalizado (o caso do critieismo de Kant é típico, dissolvido no krausismo hibérico) o que surge é um amálgama indefinido de "velho" e de "novo"

É por isto que me parece oportuna a análise objetiva, sem qualquer preocupação de demolição ou de panegírico, da concepção jurídica de João Mendes Júnior, assente numa única doutrina filosófica e infensa a qualquer forma de ecletismo.

7 - A posição de João Mendes Júnior é a de um tradicionalista integral: em Filosofia, com o seu escolásticismo; em Política, com as suas idéias monárquicas; em Direito, com o seu apêgo aos praxistas e aos Estatutos da Universidade de Coimbra.

Quanto à primeira dessas "fidelidades ao passado", motivos tinha êle, sem dúvida, para sentir-se ancorado em robusta tradição, visto como, se há um Filósofo presente na intelectualidade portuguêsa, é Aristóteles. (17-A).

subordinados às necessidades da ação ou, em pólo opôsto, como simples adornos ou brincos da inteligência a serviço de excelências verbais, e não como idéias-fôrça instituidoras ou inspiradoras de novas experiências ou de programas de vida. Devemos, porém, evitar a caracterização de nossa cultura à luz dêsse ou de qualquer outro fator isolado, mesmo porque a chamada "tendência pragmática" pode às vêzes ser interpretada como sinal de "pobreza especulativa, ou metafísica", daí resultando indevida caracterização de nossa "herança intelectual", com a condenável transposição dos problemas do plano da Filosofia para os da Sociologia e da História.

(17-A) "Desde o início histórico do pensamento português, escreve Delfim Santos, se nota uma atitude ambivalente: a metódica de uma razão que só admite o sensível como seu alimento e, no polo oposto, um pensamento de tipo metafísico de irrefragável 
Como exemplo dessa tendência, lembro aqui as Summulae Logicales do lisboeta Pedro Julião (Petrus Hispanus) que foi papa em 1276 com o nome de João XXI, cuja obra foi talvez o compêndio de "lógica nova" mais difundido na Europa no período medieval, com reedições subsequentes até o século XVII, sendo considerado, por Maurice de Wulf, um "mestre de primeira linha"

Sempre na mesma orientação peripatética, haveria que recordar a Margallea Logices de Pedro Margalho, de 1520, para chegarmos à figura, tão cara a nós juristas, de Antônio de Gouveia (Antonius Goveanus) com o seu famoso panfleto Pro Aristotele responsio, adversus Petri Rami calumnias, publicado em Paris em 1543. O humanista Antônio de Gouveia já é um aristotélico até certo ponto empenhado

coloração espiritualista. No centro, entre estas duas atitudes, essa longa série de aristotélicos, não só a mais numerosa, mas também, talvez, a melhor representada. Aristóteles é o pensador sempre presente em todos os momentos da especulação nacional. Será isto sintoma revelador de uma atitude de equilíbrio, de mesotismo, de sentido conciliador de opostos e contrários, sempre estranhos ao caráter português, quando se afirma, especulativamente?" ( $O$ pensamento filosófico em Portugal separata do livro "Portugal", Lisboa, 1946, pág. 275).

(18) op. cit., vol. II, pág. 78. Graças ao seu compêndio de Lógica nova, (nova, entendamo-nos, porque expunha todos os tratados lógicos de Aristóteles, em contraposição à Logica vetus, que não compreendia senão as Categorias e Da Interpretação, tirados do Organon, a Isagoge de Porfírio e trabalhos de Boécio) - Pedro Julião notabilizou-se pela atenção dispensada ao estudo das propriedades dos têrmos lógicos e às suas relações com os têrmos gramaticais, sendo apontado, pelo valor atribuído ao significado das palavras, como precursor da filosofia da linguagem. Cs. Paolo Rotta - La filosofia del linguaggio nella patristica e nella scolastica, Turim, 1909, págs. 176 e segs. Sôbre a importância da obra de Petrus Hispanus, sobretudo quanto aos problemas da Semiótica na Idade Média, v. J. M. Bochenski, Formale Logik, Friburgo - Mônaco, 1956, págs. 175 e segs., e passim e a bibliografia fundamental à pág. 566, inclusive quanto a atribuição da obra a Miguel Psellos. 
numa tarefa destinada a ter grande sucesso e que, de algum modo, ainda hoje prossegue, no sentido da reconquista do pensamento original e autêntico do estagirita, desprovido dos acréscimos, das deformações e até mesmo das "contaminações" sofridas pelos textos aristotélicos, dentro e fora da Escolástica. (19)

O movimento, porém, ao qual se prende mais diretamente a formação intelectual de João Mendes Júnior que jamais se propoz o problema de uma distinção entre o Aristóteles original e o Aristóteles da Escola, - é so-

(19) Cs. a edição bilingue da obra do Goveanus, Lisboa, 1940, traduzida e prefaciada por Aquilino Ribeiro, sob o título Em pról de Aristóteles. Nêste trabalho, de caráter eminentemente polêmico, embora revidando a Pierre de la Ramée, - que desfechara violento ataque à Lógica aristotélica, reputando infecunda a sua trama silogística, Antônio de Gouveia faz questão de declarar que também êle não concorda com as alterações introduzidas no texto aristotélico: "Nam suppositiones et ampliationes quas damnas, quia nunquam ipse didici, adversus te non defendo" - Ed. cit., pág. 9.

Diga-se, de passagem, que a "redescoberta" de Aristóteles, que ainda prossegue com os estudos de contemporâneos como Bonitz, Jaeger, Calogero, Ross, Hamelin, Lukasiewicz, etc. não implica, como poderia parecer, no esquecimento dos valores próprios da Lógica formal escolástica, ainda agora submetida a uma análise penetrante por Bochenski na sua monumental Formale Logik, cit., “Die scholastische Gestalt der Logik", págs. 167 usque 293. Quanto à diferença entre a teoria aristotélica do silogismo e a tradicional, durante tanto tempo confundidas, vide Jan Lukasiewicz - Aristotle's Syllogistic from the standpoint of Modern Formal Logic, Oxford, 1954, onde se lê: "Nenhum silogismo aristotélico é formu- lado como uma regra de inferência com a palavra logo, como acontece na Lógica tradicional. A Lógica tradicional é um sistema diferente da silogística aristotélica, e não deveria ser confundida com a genuina Lógica de Aristóteles" (pág. 73).

Sôbre o significado particular da obra de Antônio de Gouveia na cultura portuguêsa, vide o precioso trabalho de Joaquim de Carvalho - Antônio de Gouveia e o aristotelismo da Renascença, Coimbra, vol. I: Antônio de Gouveia e Pedro Ramo, Coimbra, 1916. Para uma apreciação geral da época, v. Lothar Thomas Contribuição para a História da Filosofia Portuguêsa, I, Lisboa, 1944. 
bretudo o da Escolástica portuguêsa do século XVI, sob a influência dominante dos padres jesuitas no Colégio de Coimbra, com Pedro da Fonseca, o "Aristóteles lusitano" e seus companheiros Manuel de Góis, Sebastião de Couto e outros mais que constituiram o grupo dos chamados "conimbricenses", famosos por seus comentários a diversos livros do estagirita, o "Cursus Conimbrisensium", "imensa enciclopédia aristotélica, no dizer de Jacques Chevalier, modêlo acabado de trabalho coletivo". (20)

Menção à parte merece a obra de outro eminente cómentarista, Frei João de São Tomás, geralmente apontado como o príncipe dos exegetas hortodoxos da obra tomista, em contraposição às inovações de Suarez, de Vasques e de Molina. O seu Cursus philosophicus ad exactam et genuinam Aristotelis ac Doctoris Angelici mentem, publicado em Madrid, em 1637, no mesmo ano do aparecimento do Discours de la méthode, não só é de significado primordial no plano metafísico, como se notabiliza por seus esclarecimentos lógicos e epistemológicos. (21)

(20) V. Jacques Chevalier, Histoire de la pensée, vol. II, La pensée chrétienne, Paris, 1956, pág. 654. Sôbre a personalidade e a obra do $\mathrm{P}$ Pedro Fonseca, v. o volume especial que the dedicou a "Revista Portuguêsa de Filosofia", Braga, t. IX, 1953, fasc. 4. De orientação prevalecentemente tomista, pois não é extranha ao seu pensamento a doutrina de Scoto, é Aristóteles quem constitui o centro de seus estudos. As suas Institutiones Dialeticarum, no dizer de Severiano Tavares, foram tomando, pouco a pouco, o lugar das Summulae Logicales de Pedro Hispano, enumerando Sommerđogel 34 edições até 1625 ("Rev. Port. de Fil.” cit. pág. 346). A sua obra fundamental, no entanto, são os Comentários à Metafísica de Aristóteles, não só pelo trabalho crítico de reconstituição do texto aristotélico, como pela tradução latina e as penetrantes considerações expendidas.

(21) Diz Chevalier que foi João de Santo Tomás quem forneceu ao P Gardeil e a Maritain a base de sua interpretação tomista (op. cit., vol. II, pág. 824). Para Maritain é êle "um dos maiores metafísicos do Ocidente moderno, enquanto Gilson se refere ao seu Cursus como "a obra prima dentre as grandes sínteses tomistas" (L'e thomisme, Paris, 1945, pág. 14). Sôbre a contribuição de Joãa de Santo Tomás no campo da Lógica formal, v. Bochenski, op. cit., 
E a razão pela qual Jacques Chevalier, estudando o movimento filosófico da Contra-Reforma, põe em relevo o papel tanto da Espanha como de Portugal, na renovação dos estudos escolásticos, que êle considera de incalculável alcance (22) e que não é possível, em verdade, englobar em uma condenação sumária, à vista dos pecos frutos colhidos pela intelectualidade portuguêsa a partir do século XVII. (23)

É inegável que foi essa a corrente que logrou prevalecer na cultura portuguêsa, mas não devemos olvidar a existência de uma outra, tôda de experiência feita, preocupada com os problemas empíricos da ciência. Não foi por mero acaso que Portugal nos deu um dos primeiros e penetrantes críticos modernos da teoria aristotélica da Ciência e da metodologia dedutivista da Escolástica, Francisco Sanches, cujo Quod nihil scitur é de 1581.

Eis como Joaquim de Carvalho focaliza, com argúcia, êste momento crucial da Filosofia portuguêsa: "Quando

loc. cit. Quanto à teoria do conhecimento, é conhecida a sua síntese expressiva da gnoseologia tomista no sentido de que conhecer uma coisa é um modo de tornar-se a coisa, sendo-se distinto dela: "Cognoscentia in hoc elevantur super non cognoscentia, quia id quod est alterius ut alterius, seu prout manet distinctum in, altero possunt in se recipere, ita quod in se sunt, sed etiam possunt fieri alia a se". Cf. Gilson - op cit., pág. 316.

(22) Chevalier, op. cit., pág. 649.

(23) Como o reconhece o P Leonel Franca, foi "brilhante mas efêmera" a renascença da Escolástica nos fins du século XVI, desde logo prevalecendo "o ímpeto que a impelia para o abismo, onde por séculos se eclipsou a sua influência histórica e doritrinal”. (Op. cit., pág. 118). O ilustre jesuita aponta, neste passu, as causas primordiais dessa decadência, além das de natureza religiosa, notadamente o gôsto de sutileza; a proliferação dos comenth́rios de comentários, com esquecimento dos pensadores do século XIII; a linguagem carregada de barbarismos; o método didático complicado em distinçōes e subdistinções; o primado da dialética, que absorve aos poucos a metafísica e a psicologia; as discussões transformadas em "logomaquias e em justas pomposas de grande aparato tecnológico"; a hostilidade contra as ciências experimentais (loc. cit.) 
deu a público em 1581, o Quod nihil scitur, haviam decorrido três anos sôbre o aparecimento em Roma do tomo I dos comentários de Pedro da Fonseca In libros metaphysicorum Aristotelis. Nestas obras, das mais notáveis que a conciência reflexiva dos portuguêses tem cogitado, opunham-se duas concepções da Filosofia e dois ideais da Ciência: uma, a do Aristóteles conimbricense, significava a restauração do pensamento dogmático e da metafísica do ser; outra, a do "cético de Toulouse", a apoteose do pensamento antidogmático e a redução da Filosofia ao plano da Ciência". (24)

Tão forte é, porém, a pressão escolástica que até mesmo a obra de Sanches, no dizer ainda do mestre de Coimbra, conserva alguns vincos de escolasticismo, assim nos têrmos com que refuta a epistemologia tradicional como no método da refutação. (25)

(24) V Introdução a Opera Philosophica de Francisco Sanches, Coimbra, 1955, pág. LIX. Quanto ao traço de empirísmo pragmático ou de preocupação pela problemática científica, não se deve olvidar a influência da cultura árabe na península.

(25) Joaquim de Carvalho, op̣. cit., pág. XXXVI. Não se pense que, com o advento do Iluminisno no século XVIII e a expulsão dos Jesuitas - que haviam dominado o "Código das Artes" de Coimbra desde 1555, - não se pense que Aristóteles tenha desaparecido do cenário cultural português. Como índice eloquente da "constante aristotélica" lembre-se que, na primeira metade do século passado, o grande jurisconsulto Silvestre Pinheiro Ferreira, o mais ilustrado dos portuguêses daquela época, e tão ligado à história de nosso País, considerava-se um continuador da linha aristotélica, na qual the parecia possível situar os ensinamentos de Condillac. Seu interesse pelo estagirita é tão grande que chega a traduzir, do original grego, o livro das "Categorias". A sua preocupação esquematizadora, o seu desejo de estabelecer distinções e subdistinções conceituais, como as que se vêm em suas Noções elementares de Filosofia Geral e aplicada às ciências morais e politicas, Paris, 1839, são sintomáticas de inegável vinco escolástico. (Cf. Miguel Reale - Horizontes do Direito e da História, cit., pág. 212). 
Raizes profundas possui, por conseguinte, o tradicionalismo escolástico de João Mendes Júnior, sendo seu mérito irrecusável ter procurado volver às fontes do pensamento tomista e superar muitos dos vícios que haviam comprometido o escolasticismo baroco português, até à reação pombalina tendente a restituir Portugal ao curso do pensamento moderno. (26)

8 - Encastelado na tradição peripatética, segundo os moldes da Escola, João Mendes Júnior mostra-se, aliás, excessivamente confiante em suas doutrinas, como se depreende da atitude metodológica assumida a-propósito da noção do que se deva entender por "próprio", exigida por seu conceito de autonomia como "direção própria daquilo que é próprio":

"Estas são as noções de Aristóteles, que para aqui aproveito; e nisto sigo o conselho de Macrobio, nas Saturnais, Livro VII, cap. VI: "Nec possum non assentiri viri cujus inventis nec ipsa natura dissentit," isto é: "Não posso deixar de concordar com um homem, de quem a natureza não discorda" (27)

Daí a tradução que nos oferece de grande parte do Livro V dos Tópicos, de Aristóteles, onde o estagirita desenvolve os problemas dialéticos relativos a algn enunciado como próprio ou não de um objeto. Após transcrever os "treze tópicos dialéticos e os vinte e cinco tópicos críticos", êle se julga credenciado a formular esta conclusão bastante sintomática dos vícios de uma pesquiza jurídica assente apenas em distinções lógico-formais:

(26) Digo que João Mendes não supera todos os vícios da Escolástica decadente, não só porque ainda dá excessivo valor a distinções puramente verbais, como também porque se mostra alheio às grandes conquistas da Filosofia. Cfr. a sua invocação de Aristóteles para pronunciar-se sôbre problemas como os tratados, por exemplo em Rev., XX, 1912/156 e 248 e segs. Quanto a êsses vícios no trato de problemas jurídicos, v. infra, ns. 9 e. 10.

(27) Rev., XIX, 1911/55. 
"Isto que aí está é uma tradução do Livro $\mathrm{V}$ dos Tópicos. Não traduzi os exemplos, para não ser longo; se reproduzisse os exemplos, muito mais iluminaria cada um dos tópicos, mas busquei ser literal e exato quanto me foi possível."

"Seja como fôr, não consegui achar, em qualquer dos Tópicos, um meio de conceber a possibilidade da autonomia para a Faculdade de Direito de São Paulo..." (28)

Fundado, "a priori", na plenitude e na suficiência da autoridade aristotélica, êle recusava à Faculdade uma autonomia que podia e devia ser caracterizada, à luz das legislação vigente e das circunstâncias fáticas, o que parece dar razão a Pedro Lessa quando, de outra feita, verberava o colega ilustre por despresar a realidade viva e palpitante da lei, afirmando certos conceitos gerais e fazendo divisões arbitrárias, "para habilmente deduzir dessas premissas o que já havia pre-concebido como a expressão do pensamento do legislador". (29)

Além do mais, ao louvar-se tão piamente em Aristóteles, estava João Mendes Júnior ancorado em um texto que não era senão uma versão escolástica ou mais precisamente, uma interpretação compendiada das lições do estagirita segundo a técnica linguística da Escola. (30)

(28) Rev., XIX, 1911/61 e seg.

(29) Rev., VII, 1899/191. Em outros escritos, incorre João Mendes Júnior no mesmo equívoco de construções jurídicas fundadas em noções dogmáticamente aceitas, como veremos logo mais.

(30) João Mendes Júnior, em mais de uma passagem, como na acima citada, louva-se na "versão" do "Organon" e de outros trabalhos aristotélicos, de autoria de Sylvester Maurus, escrevendo: "Servimo-nos da tradução latina, com o texto comentado por Sylvester Maurus, edição de Paris, 1885, sob as vistas de Francisco Ehrle e de outros jesuitas, sôbre a edição romana de 1658. Esta tradução é considerada como a melhor de tôdas" (Elementos de Lógica, cit. pág. 212, e Rev., I, 1893/102, n.ํ).

Apesar dos méritos interpretativos da obra de Sylvester Maurus, não se pode a rigor, considerá-la uma tradução, e muito menos com 
Este exemplo trago aqui para mostrar que, se a preocupação pelos "supremos princípios" deu ao nosso Autor, nos seus grandes tratados de Direito, "o segredo da clareza que resulta da ordem das idéias e da cadeia ininterrupta que as subordina uma às outras", no dizer de Manuel Carlos Figueiredo Ferraz, levou-o também a conclusões estranháveis tôda vez que pretendeu resolver problemas particulares de interpretação legal partindo de certas noções e distinções escolásticas, com perda de contato com a

as excelências acima referidas. Trata-se, em verdade, de uma reprodução sintética, de uma paráfrase dos textos aristotélicos, como o próprio título o indica: Aristotelis opera, quae extant omnia, brevi paraphrasi (sic), ac litterae perpetuo inhaerente explanatione ilustrata, Romae, 1668, trabalho incluído pelo autorizado Ehrle na reedição parisiense supra lembrada. Basta um cotejo dos "tópicos" traduzidos por João Mendes Júnior com o texto aristotélico ou com alguma das rigorosas traduções do Organon (a dirigida por W. D. Ross, por exemplo, incluida na The Works of Aristotle, Oxford University Press; a de Tricot, Organon, Paris, 1946-50, ou a mais recente de Giorgio Colli, Organon, Turim, 1955) para verificar-se como a terminologia da Escola incide sôbre o pensamento original, tirando-lhe o sentido dialético que lhe é próprio, para transformá-lo numa sêca sequência de aforismos. Já no tempo em que João Mendes Júnior traduzia os Tópicos, ou resumia o Organon (em uma síntese, aliás, digna de encômios - Elementos de Lógica, cit. págs. 199 usque 212) já havia traduções reputadas preciosas pelos melhores críticos do sistema peripatético, como, por exemplo, a latina de Pacius, Berlim, 1831 e a de Kirhmann, Lípsia, 1786-83, sem se esquecer a de Barthélemy Saint Hilaire, Paris, 184344, apesar dos defeitos que se lhe apontam.

Outra observação a fazer-se é quanto à aceitação dogmática dos ensinamentos aristotélicos, como conclusivos ou perfeitos, por sinal em se tratanajo de uma parte do Organon sujeita a fortes dúvidas, primeiro quanto à sua posição cronológica na obra do estagírita (para Solmsen, por exemplo, e muitos outros os Tópicos constituem um trabalho juvenil, ainda sob direta inspiração platônica) e, em segundo lugar, quanto à sua autênticidade, notadamente no que concerne exatamente ao Livro em aprêço. Sôbre êste ponto e as

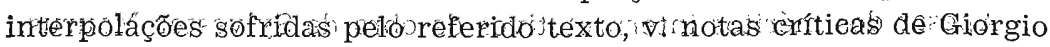

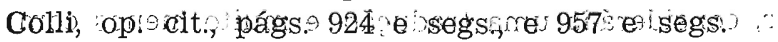


positividade jurídica. Casos que tais houve sempre que o dialético prevaleceu sôbre o homem de ciência, sendo, felizmente menos frequentes do que os momentos de compreensão da viva realidade do Direito.

\section{A metodologia escolástica e a teoria do direito de João Mendes Júnior}

9 - Nas ciências culturais, notadamente nas de tipo compreensivo-normativo, como é o caso da Jurisprudência; é sempre difícil dizer quais os resultados, positivos ou negativos, que devam ser atribuídos exclusivamente à técnica ou à metodologia empregadas, pois o coeficiente pessoal do pesquizador pode ser elemento de primeira grandeza, às vêzes decisivo. Até mesmo no campo das ciências físicas, - embora possa de certa forma ser atenuado o papel representado pelas qualidades intrínsecas do investigador, pelo menos enquanto êste se mantém nos quadros das pesquizas de caráter complementar ou acessório, supridas as deficiências pessoais pelo aparelhamento metódico e material, - é inegável a diversidade dos resultados atingidos na razão precípua da intuição, da perspicácia, da argúcia, da imaginação criadora ou da paciência pertinaz dos estudiosos que estejam aplicando processos idênticos ou análogos.

É incontestável que em alguns casos, exepcionais e de cisivos para o destino da ciência, as qualidades pessoais lograram compensar as deficiências técnicas, engendrando os meios ou os recursos lógicos de pesquiza no fluir da própria pesquiza. $E^{\prime}$ que os fatôres adequados à captação do real podem revelar-se no processo concreto da investigação, de maneira que o instrumental lógico da pesquiza e a realidade pesquizada como que surgem concomitantemente, uma e outra se ordenando na unidade criadora do labor científicoussiaí a preéariedadè dos esquêmas catalógadès a priori como compreensivos de quaisquer experiências possíi- 
veis, ou o equivoco de se absolutarizarem as formas de. conhecimento, como se houvesse conformidade predeterminada entre dadas categorias e a realidade. (31)

É, pois, sempre delicado o problema do que se deva atribuir, em mérito ou demérito, exclusivamente ao método ou à técnica preferidos na investigação.

No caso de João Mendes Júnior, talvez seja lícito afirmar-se que a sua formação escolástica produziu efeitos benéficos, assim como o conduziu a concepções de reconhecida fragilidade.

Foi êle, não um filósofo ou mesmo um filósofo do Direito, mas um jurisconsulto, no mais alto sentido desta palavra, consoante o modêlo romano de um conhecedor do justo e do injusto com base na "ciência das coisas divinas e humanas".

Bem poucos tiveram entre nós tão forte compreensão. dos liames essenciais entre a Filosofia e a Jurisprudência, mesmo porque, parafraseando Francis Bacon, um medíocre conhecimento do Direito arreda da Filosofia, enquanto que o saber jurídico profundo reconduz a ela.

Seguindo as lições da Escolástica com destemor, em uma época de aguerridos seguidores de A. Comte ou de H. Spencer, teve êle o mérito de evitar as soluções ecléticas em que se justapunham Kant, Krause, Rosmini e o Syllabus (32), e procurou sempre manter a unidade sistemática das suas concepções. Daí também o repúdio ao equívoco de uma cadeira da "Enciclopédia Jurídica", creada "para traçar o centro, a circunferência, os raios e as tangentes da Ciência jurídica", acostumando o estudante ao "de omnibus aliquid, de toto nihil".

(31) Sôbre êsse problema, v. meu "Para um criticismo ontognoseológico", em Horizontes do Direito e da História, S. Paulo, 1956, p. 334 e segs.

(32) V. minha Doutrina de Kant no Brasil, S. Paulo, p. 68: e segs. 
Do ponto de vista metodológico o que distıngue, desde logo a sua obra é uma admirável preocupação de clareza e de rigor conceitual. Êle è bem um herdeiro espiritual de Santo Tomás em certas fórmulas que se tornaram clássicas em nossa Jurisprudência, revelando o seu respeito ao valor intrínseco das palavras e das definições, pois, no dizer preciso de Joaquim de Carvalho, "com Aristóteles todo o ensino escolástico, de sentido realista, tem por indubitável que saber é definir e que, consequentemente, a definição perfeita exprime a essência da coisa definida e resume o saber acerca dela". (33)

Outro mérito, e é por certo o que lhe assegura lugar de primeira grandeza entre os nossos jurisconsultos, é o da unidade sistemática, o travamento lógico coerente de seus escritos, com base em cuidadosa análise das fontes históricas, qualidades que noto sobretudo na que considero a sua obra prima, O Processo Criminal Brasileiro, aquela em que menos se percebe, aliás, o aparato verbal da Escola, cuja disciplina metódica governa, todavia, tôda a arquitetura do trabalho. (34)

Em uma terra onde pululam, como cogumelos, os exegetas de leis e de regulamentos, êle se notabiliza pela preocupação teorética da Jurisprudência, pela convicção firme de que não há problema de Direito solto, desprendido das exigências fundamentais do sistema, insuscetível de ser re-

(33) Op. cit., p. 35

(34) Ao contrário de seu Direito Judiciário Civil, onde o escolasticismo exterior se revela a cada passo, repisando escritos anteriores, no Processo Criminal Brasileiro a linguagem flui sem escoras aparentes, livre das distinções escolásticas e de sua terminologia arcaica, salvo no prefácio, onde cuida de "ato primeiro remoto", "ato primeiro próximo" e "ato segundo", para provar que "tudo quanto se refere ao direito de agir e à capacidade das partes não pertence às leis do processo, mas às leis civis, comerciais, e criminais, por analogia chamadas leis substantivas", - ou então, quando invoca a teoria das quatro causas para estudar a nulidade do processo como razão de "habeas corpus". Cfr. op. cit., 3.a ed., Rio, 1920, Prefácio e vol. II, p. 333 e segs. 
conduzido ao encadeamento das normas superiores. A subordinação lógica, por exemplo, da atividade jurisdicional e, por derivação, de todo o processo, às regras e princípios informadores de natureza constitucional, é, entre muitos, um exemplo de sua "arquitetônica jurídica".

Harmonizava-se com a sua formação escolástica o amor pelos velhos ensinamentos do direito reinol, o qual, como já dissemos, constitui a outra componente essencial de seu espírito.

10 - Ao lado dêsses méritos, que se casam a uma erudição fora do comum sôbre as fontes históricas de nossa legislação, não há como ocultar a fuga para o abstratismo formal, em mais de uma passagem em que as noções e as fórmulas passam a ter validade por si, perdido o seu sentido de referibilidade ao concreto, como se nelas já se contivesse de antemão a essência da realidade mesma, e como se, para o conhecimento desta, bastasse o desenvolvimento silogístico daquelas.

É o que noto, por exemplo, quando polemiza com Pedro Lessa asseverando a competência da União, no regime da Constituição de 1891, para "legislar privativamente sôbre -o direito de ação e as condições de seu exercício", as formas dos atos probatórios, e, de maneira preferencial sôbre direito processual, partindo de um jôgo de distinções entre "substância" e "acidente", "matéria" e "forma", "atributo essencial", etc., abstração feita dos elementos históricos e sistemáticos. (35)

o mesmo se diga com relação ao problema jurídico da autonomia das fundações ou das corporações, que lhe parecia lògicamente impossível em virtude de argumentos especiosos típicos da Escolástica decadente, como êste: “sendo uma fundação uma só substância, não podem coe-

(35) V a polêmica João Mendes Júnion - - Pedro Leśsa na Rev. Fac. Dir., v. XII, 1899: 101 e seg.̉. 
xistir nela duas personalidades, por exemplo a personalidade do Estado e ao mesmo tempo a personalidade da fundação", pois, "fatalmente, a personalidade do Estado, como instituidor, absorve a da fundação que êle criou, constituiu e organizou" (36)

11 - Felizmente, essas e outras descaídas para o formal e o vazio são raras, não comprometendo a obra do mestre João Mendes Júnior, que ainda hoje é basilar em nossa Jurisprudência, não só pelas qualidades acima apontadas, mas também pela admirável simbiose de exigências teoréticas e práticas, consoante a orientação metodológica que desenvolve num precioso trabalho intitulado " $\mathrm{O}$ ensino do Direito".

Neste estudo, elaborado quando diretor da Faculdade de Direito no biênio de 1913-1914, o nosso Autor fixa com clareza a sua posição metodológica perante a problemática jurídica.

(36) Rev. XIX, 1911/70. Como se vê todo o chamado "Direito Autárquico" que, em razão de sucessivos desmembramentos perso. nalizados do Estado, veio dar novos rumos ao Direito Público, seria incompreenssível à luz dessa "substancialização" do conceito de pessoa jurídica, cuja exata compreensão sòmente surgiu quando o problema foi situado no plano das "realidades normativas", como criação do Direito segundo a Lógica que lhe é peculiar, e não segundo esquêmas abstratos que se queiram impor "a priori" às exigências da vida social. Para outro exemplo do processo escolástico de tratamento de problemas de Direito, vide também na Rev. IV, 1896/185 e segs., as considerações expendidas sôbre a técnica de inquirição de testemunhas, segundo a cautela de Mendes a Castro, ou seja, com base nas dez categorias ou predicamentos de Aristóteles. É a mesma via seguida para dar-nos êste rebarbativo conceito a lei: "A lei, como preceito comum, é uma substância, e , como tal, é afetada pelos outros predicamentos ontológicos, isto é, pelos nove acidentes" E, por inferência, êste outro conceito de ação, em discrepância com todo o progresso do

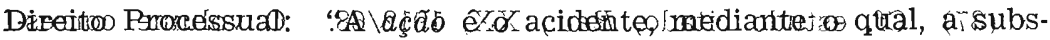

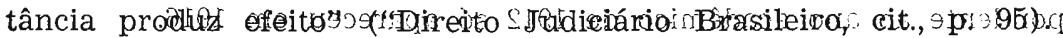


Diz êle que o método analítico-sintético ou empírico-racional se impõe de tal modo nas Ciências sociais e jurídicas, que dêle nenhum professor conseguirá se afastar, "qualquer que seja a sua tendência, quer para as exagerações idealísticas de Fichte, Schelling, Hegel e outros, quer para a aplicação universal do processo matemático, segundo Descartes, ou segundo Augusto Comte." (37)

Afirmando ser contrário ao absoluto empirismo indutivista, nem ter como absoluto o processo meramente dedutivo, êle proclama, todavia, invocando Sêneca: "sem os princípios fundamentais, ninguém chega à verdade, de sorte que, na realidade, não há demonstração sem princípios", o que o leva a limitar, nas ciências morais, o método indutivo à verificação de fatos particulares, subordinando-o à evidência dos primeiros princípios e às verdades neles fundadas.

Vale a pena transcrever aqui as asserções que faz a respeito:

“1. ${ }^{\circ}$ - Os princípios da demonstração são juízos dos quais outros juízos procedem imediata ou mediatamente. Uns são comuns a tôdas as ciências; outros são comuns a cièncias do mesmo gênero; outros são próprios de cada ciência.

" $2 .{ }^{\circ}$ - Ninguém sèriamente dirá que, para firmar os princípios comuns a tôdas as ciências e os princípios comuns à ética geral, isto é, a tôdas as ciências morais, o professor de Direito tenha necessidade de usar do processo da indução. Os preceitos de Direito, que decorrem dêsses princípios comuns, são lògicamente formados por dedução, como partes contidas no todo.

"3. ${ }^{\circ}$ - Quanto aos princípios próprios da ciência do direito e dos quais decorrem certos preceitos especiais, sòmente êsses necessitam ser firmados por indução e ilação

(37) Cf. estudo citado, Rev., XX, 1912/68. O volume correspondente ao ano acadêmico de 1912 só apareceu em 1916. 
das séries de fatos. Tais preceitos especiais são conclusões que, em relação à série de fatos, são como o todo em relação às partes.

“4." - Em geral, denomina-se ensino prático aquêle que consiste na observação dos casos consumados ou julgados, e no exercício de aplicação a casos figurados. Ora, a crítica dos casos consumados e dos casos julgados é um instrumento teórico que pode convir, não principalmente para indução, mas como prova de conclusões obtidas pela dedução; realmente prático é sòmente o ensino da aplicação a casos figurados, com a rememoração das cautelas especiais, relativamente a atos com fórmulas solene, tais como contratos, testamentos, atos de protocolo, atos de registro, atos e têrmos do processo, em geral, as formalidades de atos praticados em ofícios públicos e em auditórios judiciais.

" $5 .{ }^{\circ}$ - Este ensino prático só tem oportunidade nas matérias de Direito Civil, Direito Comercial, Processo Civil, Processo Comercial, Processo Criminal e Medicina Pública, únicas em que poderia ser cabível um exame com prova prática. Nos outros ramos ou matérias da ciência jurídica, assim como na Economia Política, Direito Público, Direito Internacional, êsse ensino só pode consistir em visitas a estabelecimentos industriais e a instituições sociais e em despertar a atenção para o movimento social econômico e administrativo." (38)

É à luz dêsses princípios metódicos que devemos compreender o que João Mendes denomina "método empírico-racional", ao discriminar a índole das diversas ciências:

(38) Rev. cit. p. 69. "O Direito, afirma êle em outro passo, é uma ciência prática, fundada na justiça, que é uma virtude moral; mas por isso mesmo, o Direito supõe o entendimento dos primeiros princípios, supõe a ciência que por obra da razão forma os preceitos, não só por indução dos fatos como por dedução dos princípios, supõe a contemplação das causas mais altas dos preceitos" (loc. cit. p. 59). 
"Tôdas as ciências não podem ser tratadas pelo mesmo método: as ciências morais não podem ser reduzidas sòmente à indução dos físicos, assim como não podem ser reduzidas sòmente à dedução dos matemáticos. Assim, as Ciências Juridicas, quando possam partir da observação dos fatos para os preceitos e dos preceitos para os princípios, uma vez firmados os princípios, hão de lògicamente regressar dos princípios para os preceitos e dos preceitos para os fatos" (39)

Após a crítica do casuismo dos glosadores e do "case-method" anglo-saxônio, João Mendes Júnior faz um confronto entre os Estatutos da Universidade de Coimbra, de 1772, e a Exposição de Motivos que precederam as leis portuguêsas que em 1911 deram nova estrutura às suas Universidades.

Tradicionalista até à medula, as preferências de João Mendes Júnior vão para o que chama "o método pragmático" dos Estatutos de 1772, os quais, como se sabe, serviram de base aos elaborados pelo nosso Visconde da Cachoeira, quando da instituição dos cursos jurídicos no Brasil em 1827.

À primeira vista pode causar estranheza que um escolástico, tão cioso de suas convicções doutrinárias, manifeste tanto entusiasmo por uma obra que foi peça mestra na politica do Marquês de Pombal em sua luta contra a "Filosofja dos àrabes" A realidade é que aquêles Estatutos, apesar de todos os seus propósitos de racionalismo iluminista, não se divorciam completamente da tradição da

(39) Rev. cit., p. 46. É neste mesmo trabalho que João Mendes Júnior faz a crítica do empirismo integral de Stuart Mill, por considerá-lo assente no conhecimento sensível, que não pode ir além do singular, do contingente e do material: "o exclusivismo do método empírico redunda na negação do princípio de causalidade, isto é na afirmação de que os princípios, mesmo axiomáticos, nada mais são do que generalizações dos fatos fornecidos pelos sentidos ? pela consciência, os quais se confirmam pelo hábito ou pelo costume" (loc. cit., p. 46). 
Escola, mas apenas a depuram e a acomodam a novas condições histórico-sociais. (40).

Para o nosso jurisconsulto, aquêles Estatutos consagram ainda o que há de melhor em matéria de ensino jurídico, porquanto colocam a prática no terreno da realidade, mas com subordinação aos primeiros princípios:

"O método do ensino superior, destinado a guiar o exercício de profissões liberais, não pode deixar de ser o mesmo método das respectivas atividades, isto é: contemplar os princípios e causas, deduzir os preceitos, e aplicar os preceitos aos fatos, afim de que êstes sejam praticados ou julgados com as necessárias cautelas e fórmulas.

“No ensino do Direito, portanto, assim como não há vantagem em usar de um método exclusivamente teórico, também não há vantagem em usar de um método predominantemente prático". (41)

12 - Seria falha esta análise da metodologia escolástica na doutrina de João Mendes Júnior se não fizesse uma breve referência à sua arte de disputar sôbre um têma

(40) Como lembra Cabral de Moncada, se os referidos Estatutos exaltam o "tribunal da razão", não deixam de estipular, no $\S 15$, que as opiniões do professor sejam sempre confrontadas com a "doutrina revelada", pois, "só achando-as a ela conformes, se darão por seguras": "a revelação será a bússola que o guie e a rémora que o contenha no seu entendimento" (op. cit. p. 137, n. 1).

(41) Rev. cit. p. 59 . Na realidade, o métođo do ensino preconizado nos Estatutos de Coimbra, de 1772, implicava na realização de exercícios de Prática Forense, segundo as Jurisprudências euremática e formulária, a que farei referência logo mais, e que não teve maior êxito no Brasil, onde predominam até hoje as "lições magistrais" Só muito recentemente, e assim mesmo no meio do ceticismo ou da incompreensão de alguns, tende-se a optar por outros processos, por cursos práticos de ampla investigação ciêntifica, e não de mera praxe forense, nos limitados horizontes dos antigos Estatutos conimbricences. Foi pena que João Mendes Júnior, com a sua autoridade, não houvesse comprendido ou aco- 
proposto, à sua "dialética" inspirada nos Tópicos aristotélicos.

Não é apenas na polêmica com Pedro Lessa que se revela essa capacidade de argumentar, visando a demonstração de suas teses e os equívocos do adversário, se possível tirando partido das asserções contraditadas em benefício próprio.

Neste sentido, são bastante expressivas as páginas de crítica dedicadas a ilustres representantes das teorias positivas no campo do Direito e da Sociologia em São Paulo, nos fins do século passado, João Monteiro e Paulo Egydio.

Apreciando a Teoria do Processo Civil e Comercial, editada em 1899, João Mendes Júnior começa por discordar de João Monteiro quanto ao título da obra, pois, a seu ver, deveria ser empregada a locução Direito Judiciário, visto como a doutrina das ações não entra tôda na doutrina do processo, mas apenas na sua acepção formal, o mesmo se dando com a doutrina das provas. Ficava, assim, caracterizada, desde logo, a sua posição tradicional, correspondente a uma definição da disciplina, "mais velha e mais simples" do que a proposta pelo colega, "não só por ser mais dialética", mas também por parecer-lhe "de melhor aviso não sair dos antigos arraiais”. Não o tenta, nesse ponto,

Thido o espírito novo que, apesar do "enciclopedismo filosófico", se nota na Exposição de Motivos das leis portuguêsas de 1911, especialmente quando nela se encontram diretivas de grande acêrto pondo em relevo "o diálogo entendido como categoria pedagógica", e, sobretudo, o íntimo e indissolúvel liame que deve existir entre ensino e pesquiza científica, e não apenas entre a aquisição de certos conhecimentos e os exercícios de prática profissional. São da referida "Exposição de motivos" estas afirmações essenciais: "a escola superior não tem por fim exclusivamente, nem sequer principalmente, transmitir aos alunos a ciência feita; mas é sua missão ainda ensinar os processos de investigação científica, promover a organização de trabalhos originais, e assim concorrer para o progresso da ciência" (Cf. Rev. cit. p. 54 e segs., onde João Mendes Júnior transcreve os trechos principais da Exposição no tocante ao ensino jurídico). 
a orientação dos grandes processualistas italianos da épocả, Mortara e Mattirolo, que detiveram o bastão da "proces'sualística" até o advento renovador de Chiovenda e de seús continuadores conferindo à Itália irrecusável primado ná matéria. Após criticar as distinções puramente analógicas de Bentham entre leis substantivas e adjetivas, - reiterando a sua tese de que não era lícito usar das expressões leis adjetic'as e direito formal como equipolentes à expressão direito processual, - passa à análise da posição filòsófica de João Monteiro, que, resolvendo usar da técnica positivista e spenceriana, preferira falar em linhas embriológicas do Direito Judiciário para substituir o principium existendi dos Escolásticos, ou em necessidades políticas ao invés de principium essendi.

É aqui que aparece o dialético, para mostrar, com finura, que João Monteiro, no fundo, não estava sendo fiel aos ensinamentos de seus mestres Spencer e Cogliolo, cujas teorias o crítico mostra conhecer nas fontes, apontando a impossibilidade de aplicar-se a "hipótese da evolução spenceriana" nos domínios da Moral, no campo do Direito e da Sociologia. Vale a pena ler essa resenha não só para verificar a altitude da crítica, como a nobreza de seu espírito reconhecendo, embora em divergência de idéias, ós méritos de "um livro magnífico, onde há muito que aprender e onde há muitos elementos para desafiar o nosso estudo".

Outro exemplo de arte dialética encontramos na crítica de um trabalho de Paulo Egygio intitulado Do conceito geral do crime (43), no qual podemos, outrossim, apreciar a opinião de João Mendes Júnior sôbre várias questões fundamentais, como a do livre arbítrio e do determinismo. “Pelo fato, diz êle, comentando Claude Bernard, da vontade

(42) Cf. Rev., VII, 1899, p. 7 segs.

(43) V. Rev. vol. VIII, 1900, p. 35 e segs. 
se exercer em um meio determinado, não se segue que ela seja necessitada. Ninguém põe em dúvida que os impulsos para o ato podem provir, e quase sempre provêm, de nossa natureza; que nossa natureza é um resultado da herança, das circunstâncias, da educação. Mas uma coisa é a volição, outra coisa é o livre-arbitrio: na volição entram todos êsses fatôres e mais o livre-arbítrio, que é também um fator." Daí as suas críticas à metodologia sociológica de Durkheim e à Sociologia Criminal da Escola italiana.

É a teoria de Durkheim que concentra a sua atenção, não só quanto à atitude metódica de "considerar os fatos sociais como coisas", como especialmente pelo seu conceito de "normalidade" na verificação objetiva dos crimes, desenvolvendo uma série de objeções, inclusive de ordem teológica, situadas em um plano totalmente distinto dos propósitos reais do sociólogo francês. (44)

A jurisprudência segundo um mestre da tradição

13 - As considerações até aqui expendidas comprovam a minha afírmação inicial sôbre a sua preocupação dominante pelos estudos de Lógica e de Epistemologia. Vejamos agora como é que, à luz dos princípios da Escola, êle se manifesta sôbre o conceito de Direito e a Jurisprudência.

Desnecessário é dizer que êle se inspira nos ensinamentos tradicionais do Direito Natural, entendido como lei natural ou moral, a qual se se funda em dois primeiros princípios: "Deve-se fazer o bem e evitar o mal"; "é necessária a ordem tanto na vida individual como na vida social; para conservação da espécie humana" Acrescenta-lhes os três primeiros preceitos já lembrados no Digesto:

(44) Ibidem, p. 48 e segs. 
viver honestamente, não lesar a outrem, atribuir a cada um o que é seu. (45)

Subordinada a êsses princípios e preceitos desenrola-se a experiência do Direito, o qual è por êle concebido sob tríplice perspectiva: como atributo da pessoa, como fenômeno na vida social, e como norma de agir ou lei. Sintetizemos com as suas próprias palavras:

"Como atributo da pessoa, o Direito é a faculdade de agir moralmente inviolável. Neste sentido, chama-se Direito Subjetivo.

"Como fenômeno, isto é, tal como nos aparece no mundo sensível, (sic) o Direito é uma relação da vida social. Neste sentido, chama-se Direito Objetivo Material.

"Sob um terceiro aspecto, o Direito é concebido como norma ou lei. É o chamado Direito Objetivo Formal. É a forma genética e obrigatória da ordem social, "a lei tornada positiva".

O Direito, em sua realização na vida social, é a vontade geral, a vontade de uma Nação, tornada concreta e viva na pessoa privada. (46)

14 - Fixados assim os três aspectos do Direito, passemos à sua noção de Jurisprudência.

Os velhos Estatutos da Universidade de Coimbra, a cujas diretrizes se mantém sempre fiel (47) ainda vão lhe fornecer o modêlo da Ciência do Direito ou Jurisprudência: nâo será exagero dizer que João Mendes Júnior é, sôb certo prisma, o teorizador dos preceitos conimbricences, ajustados àos esquômas escolásticos.

(45) Rev., vol. XX, 1912, p. 69. Ao problema do Direito Natural João Mendes Júnior não dedica estudos especiais: êle dá o problema como pacífico, cuidando mais de suas repercussões no plano da legislação.

(46) Direito Jud. Bras., cit. p. 3 e segs. e 32, nota.

(47) Confrontam-se Rev. vol. I, 1893, p. 142 e, vinte anos depois, Rev. v. XX, 1912, p. 66. 
O seu ponto de partida é a distinção entre intelecto simpiesmente especulativo e intelecto prático: o primeiro "contempla princípios e fenômenos para deduzir e induzir leis, cuja aplicação não depende de nosso poder, ou não está em nossa intenção"; o segundo "contempla os princípios e fenômenos para deduzir e induzir leis, cuja aplicação depende de uma atividade livre, e está em nossa intenção".

Lembra tal distinção, com apoio em uma passagem do Cap. VI da Perihermenias de Aristóteles. Esclarece que, no seu modo de ver, dois êrros devem ser evitados: o de Kant ao afirmar que não são "duas modalidades de uma mesma potência, mas faculdades ou potências especìficamente diferentes, às quais deu o nome de razão pura e razão prática"; e, outrossim, "a confusão deplorável entre intelecto especulativo e intelecto teórico."

Êste segundo ponto é de grande alcance na sua doutrina do Direito, casando-se admiràvelmente com o seu repúdio a qualquer esfôrço especulativo destituído de "possibilidade de aplicação". Defende êle ardorosamente, por conseguinte, o valor prático de suas distinções escoláticas, com fundamento na afirmada "adequatio rei et intellectus".

Vale a pena insistir sôbre a atribuição que êle faz da qualidade teorética a tôdas as indagações, quer versem sôbre a ordem especulativa, quer sôbre a ordem prática:

“A palavra teoria - deriva-se do vocábulo grego teoros, que significa contemplar; ora, a necessidade de contemplar aparece tanto na ordem especulativa como na ordem prática. $\mathrm{O}$ intelecto simplesmente especulativo considera o ponto de vista da verdade e não se extende ao ponto de

(48) Rev., vol. I, 1893, p. 102, nota 1. Manifesto, como se vê, é o contraste com a posição de Pedro Lessa que, desde aquela época, louvado na distinção de Stuart Mill entre Ciência e Arte, a primeira de natureza indutiva e dedutiva a segunda, contestava a existência de ciências práticas. (Cf. minha Fillosofia do Direito, vol. I, t. II, p. 291 e seg. 
vista da operabilidade; o intelecto prático não abandona o ponto de vista da verdade, mas extende-se à operabilidade e depois à operação. Depois que, a propósito de um caso particular, o intelecto especulativo contempla a verdade dos princípios, dos fenômenos e as leís que daí se deduzem ou induzem, o intelecto prático passa a contemplar a operabilidade, isto é, as cautelas e as fórmulas necessárias à exequibilidade da operação.

“Não há, pois, incompatibilidade entre a teoria e a prática, ao contrário uma teoria que não é praticável ou é falsa, ou, pelo menos, é incompleta. Por isso se diz que a comparação com a experiência é a pedra de toque de tôda a teoria". (49)

15 - O problema da realizabilidade ou da praticabilidade como exigência essêncial do Direito é um traço marcante na doutrina de João Mendes Júnior, que se compraz em ver as suas convicções, assentes em velhos ensinamentos, também confirmadas pelo insuspeito Rudolf von Jhering. No seu modo de entender, pertence o Direito ao tipo daquelas ciências que são "especulativas sob um ponto de vista e práticas sob um outro":

"O Direito é uma Ciência especulativa quanto ao modo de saber e prática quanto ao fim, porque o Direito é para ser aplicado aos fatos particulares e contingentes da vida humana.

"Daí decorre que a principal condição da teoria jurídica é a realizabilidade. O Direito, diz Jhering, (Espírito do Direito Romano, I, 16 e segs.) existe para ser realizado. . Aquilo que não é realizável não é direito". (50)

À questão da realizabilidade volve êle logo depois, insistindo:

(49) Rev. cit., vol. I, 1893, p. 102 e seg. Cf. também Dir. Jud. Bras., cit., págs. 1 e segs., onde, volvidos vinte anos, se repro. duzem os mesmos conceitos.

(50) Rev., vol. I, 1893, p. 104 e segs. 
“Entretanto o Direito é para ser realizado. Não basta, pois, a verdade das regras jurídicas; é necessário ainda a sua realizabilidade. O homem de ciência contempla principalmente a verdade jurídica, sem desconhecer que esta verdade deve ser realizável (sic); o homem da lei busca os meios de transformar as regras em preceitos, tendo $\mathrm{em}$ vista principalmente a realizabilidade. O legislador, confeccionando preceitos relativos à matéria e à forma das relações de Direito, tem a tarefa subordinada às condições peculiares da vida de um povo, non ut ex regula jus sümmatur, sed ex jure, quod est, regula fiat:" Também neste passo, João Mendes Júnior invoca um precioso ensinamento de Jhering: "Eu distingo a realizabilidade material da realizabilidade formal do Direito. A segunda consiste na facilidade e segurança da aplicação do Direito abstrato às espécies concretas" (51)

É, a seu ver, a mesma orientação firmada nos citados Estatutos da Universidade de Coimbra, de um sentido pragmático vigoroso: "A aplicação das leis aos casos é o fim de todo o conhecimento do direito. $\mathrm{O}$ que distingue o jurisconsulto perfeito não é a simples e nua ciência e inteligência das leis, pois que esta apenas pode formar um jurisperito, mas que é sim a ciência da aplicação. ; só esta é que pode qualificar-se de Jurisprudência"

16 - O caráter especulativo-prático do Direito implica em discriminar três grandes ordens de conhecimento jurídico, visto como o intelecto prático se manifesta como prudência e como arte.

(51) Rev. cit. p. 112. O seu conceito de "realizabilidade do Direito" é tão acentuado que João Mendes Júnior, chega a surpreender-nos com uma afirmação que poderia ser subscrita por um empirista integral: "O Direito nasce do fato; aquêle não se realiza sem êste; um não se separa do outro; afirmar que uma lei não é aplicável é o mesmo que não aplicá-la" Dir. Jud. Bras., cit. p. 15. 
Daí a discriminação, ou melhor, a apreciação da Jurisprudência ou Ciência do Direito sob três aspectos, a saber:

a) como Jurisprudência simplesmente teórica;

b) como Jurisprudência prática fundada na prudência, ou Jurisprudência euremática;

c) como Jurisprudência prática realizável pela arte, ou Jurisprudência formulária.

Há entre êsses três aspectos uma subordinação lógica necessária, pois se a arte preestabelece as fórmulas, e se cabe à prudência decidir sôbre a oportunidade moral de sua aplicação, é a ciência que antes fornece os princípios e as leis. No momento artístico da aplicação ou realização do Direito, esclarece João Mendes Júnior, "na frase de Bacon, as fórmulas manifestam as mais recônditas prescrições das leis, à semelhança da mão fechada que se abre: ad instar pugni et palmae" Ao mesmo tempo que a teoria assim se manifesta e se atualiza, afirma-se a virtude moral da prudência, com as suas cautelas, ditadas pelo bom senso, a sagacidade e a resolução, pois o verdadeiro jurista deve ter perspicácia para julgar do que vai fazer ainda nas minimas circunstâncias, vivacidade de espírito, combatividade, etc. (52)

Para o Direito passar do estado de possibilidade para o de atualidade; do estado de realizabilidade para o de realização hic et nunc, depende, como se vê, das cautelas da prudência e das fórmulas da arte. Por mais que haja ciência, prudência e arte, será, todavia, necessário algo mais para ser-se jurista: "Nunca, porém, o artista será completo sem amor ao trabalho e sem hábito de exercitá-lo. O hábito torna o trabalho fácil e até agradável; pelo hábito a arte se identifica com a vida do artista" (53)

17 - A Jurisprudência simplesmente teórica estabelece os princípios gerais, fixa os preceitos, observa as rela-

(52) V.Rev. cit. p. 105 e segs.

(53) Ibidem, p. 106 e 109. 
çỗes sociais, demonstra as regras e interpreta as leis, "abrangendo a ciência e a legislação". (54).

A Jurisprudência Prática tem por fim "a aplicação das leis aos fatos e casos ocorrentes no fôro", desdobrando-se no estudo das cautelas ou euremas, e na confecção das fórmulas, ou por outras palavras, nos elementos artísticos. e formais dos fatos jurídicos, quer judiciais, quer extrajudiciais.

Há, assim, na concepção de João Mendes Júnior, uma. correlação inegável entre teoria e prática do Direito, mas. através de um escalonamento de pesquizas e segundo uma tẹrminologia e uma técnica que não me parece possam atender ao espírito de nossa época.

Não bastará, em verdade, elaborar antes uma Ciência. Jurídica como entidade (" Direito, diz êle, como ciência ou como pura teoria, tem entidade; mas para passar do estado de entidade para o de existência etc. etc. Rev. 1893/106), para só então se cuidar de projetá-la como. momento da realização ou da prática do Direito. A conexão ou implicação entre teoria e prática deve ser um pressuposto metódico válido tanto no momento da elaboração dos princípios, das leis e dos institutos jurídicos, como no da sua interpretação e aplicação: temos, em suma, um. entendimento diverso sôbre o que seja "prática", não redutível aos horizontes profissionais do fôro. Quem estuda. aliás, as páginas que João Mendes Júnior nos legou sôbre Prática Forense (55) pode verificar que o ilustre jurista. embebe de cogitações teóricas os seus estudos de cautelas e fórmulas, enriquecendo o têma com ampla apreciação da

(54) Rev. cit. p. 117 e Rev. Fac. Dir. vol. XX, 1912, p. 63. Parece-me obscuro o emprego das expressões "ciência e legislação" como objeto da Jurisprudência puramente teórica, pois ela mesma ou é a ciência, ou não sei o que seja.

(55)' São vários artigos publicados pela Rev. da Fac. de Direito e que mereciam ser reunidos em volume, assim como outros escritos, não fôsse a tristeza dos tempos no que se refere a assuntos. de indagação pura. 
História do Direito e do Direito Comparado, mesmo porque a. experiência tem revelado quanto são estéreis os formulários e as receitas de "prudências", que não representan momento da Jurisprudência, nem podem ser confundidos com o Direito como realidade concreta.

\section{O problema João Mendes Júnior na cultura brasileira}

18 - Não foi meu intúito, ao iníciar êste trabalho, oferecer conclusões, nem muito menos fazer o balanço dos ensinamentos de João Mendes Júnior sob o prisma da Filosofia. Há estudos que não alimentam o propósito de demonstrar uma tese, nem de chegar a resultados como os que, no campo de certas ciências, representam a única razão de ser ou o título de legitimidade da pesquiza.

Quando analisamos produções literárias ou científicas, situando-as em função das qualidades pessoais de seu autor e das conjunturas do seu tempo, a pesquiza flui no plano da pura compreensão objetiva; move-se segundo as exigências de captação dos sentidos da obra cultural, livre do propósito, muitas vêzes penoso e comprometedor, de converter a vivência crítica dos problemas em algo de quantificado e dogmático.

À luz da Sociologia do conhecimento, tais pesquizas talvez possam, no entanto, valer como pontos essenciais à interpretação de uma época, bem como para a determinação dos fatores atuantes em suas formas de saber científico, esclarecendo alguns aspectos do processo intelectual de dado. período histórico.

O que mais me seduz na personalidade de João Mendes Júnior é o talhe nítido e inconfundivel de sua vida e de sua obra, formando uma unidade acabada de pensamento e de ação. Em uma terra onde proliferam caçadores da "última verdade", êle amou corajosamente as "verdades antigas" e extremou-se no carinho pelo passado, até mesmo anacrônicamente, vivendo o presente como passado, ao contrário dos historicistas que vivemos mais sábiamente o pas- 
sado como presente e como futuro; em um meio tocado pela sofreguidão do imediato e do empìricamente útil, êle soube cultivar as perguntas "que não servem para nada"; convivendo com juristas, cujos horizontes são muitas vêzes delimitados pelas paredes angustas do Fôro, êle sentiu a fôrça universal das idéias do Direito e da Justiça, sem perder contato com a prática, dobrando-se sempre às suas exigências inexoráveis; num país de ecléticos, de conciliadores de múltiplas verdades, êle quiz ser rìgidamente escolástico, no fundo e na forma, conhecendo os modernos mas não se deixando seduzir por êles; ensinando entre homens confiantes no poder da intuição e seduzidos pelos repentes da inteligência improvisadora, êle porfiou em reclamar o aprendizado metódico e perseverante, apontando para os valores da "atenção" e da "memória": a sua originalidade maior consiste em jamais ter querido ser original, inovador, surpreendentemente atual e novo. Figura extremada, quase o paradigma de uma certa forma de conceber o universo e a vida, isola-se em seu tempo e projeta-se até ao nosso, como um problema na significação de nossa cultura.

Sim, porque João Mendes Júnior seria inconcebivel fora das coordenadas da cultura íbero-americana, sendo, assim, a expressão ou o sintoma de algo que se prende muito fundo às raízes de nossa formação mental.

Se êle tivesse sido um escolástico ortodoxo, sem êxito e sem repercussão duradoura na vida jurídica do país; se êle não tivesse sido um verdadeiro chefe de escola na processualistica nacional, e se o seu rígido tradicionalismo, não houvesse representado como que "fôrça nova" na componente de nossa Jurisprudência, não haveria razão para o "problema" que me proponho, nem faltariam exemplos de estudiosos com tendências análogas na Itália ou na França, na Alemanha ou nos países anglo-saxônios.

$O$ que é singular, portanto, é a repercussão de suas idéias em São Paulo, especialmente na geração seguinte, ou seja, passado o chamado "predomínio positivista", à 
medida que ia declinando a influência de Pedro Lessa ou de João Monteiro, os quais, apesar de sua desmedida confiança nas ciências das coisas para a solução dos problemas humanos, correspondiam nıais à projeção futura de nossa intelectualidade e à concretitude de nossos problemas.

É claro que em tôda parte se projetam vitoriosamente juristas conservadores, como os há progressistas e revolucionários. A dimensão cultural de João Mendes Júnior é, porém, diversa, bem distinta da dos mestres da Jurisprudência neo-tomista, que sabem ou procuram ser contemporâneos, embora aplicando, desenvolvendo ou retificando as teses do Aquinate em seus valores essenciais. O que o torna um "problema" deveras sintomático é a "atualidade" de um homem "inatual", que compromissos não tinha senão com o passado.

19 - Tecendo considerações sôbre o futuro do sistema de Santo Tomás, A. D. Sertillanges discrimina os três métodos que poderiam justificar, hoje em dia, o título de "neo-tomista"

O primeiro consiste em elaborar conclusões novas a partir dos principios ou das conclusões provisórias de Santo Tomás, processo êste já explorado há séculos, pela nuvem dos comentadores, e que deve ser considerado verdadeiramente esgotado. Êsse trabalho de mera inferência não se concilia mais com o espírito moderno, exprimindo-se em um plano de pensamento que não é o nosso, máxime quando se recai em aberração símile à de Averróes que considerava "concluída a ciência" com Aristóteles.

O segundo método, continua o professor do Instituto Católico de Paris, visa proceder mediante adições justapostas de doutrinas recentes, destinadas a confirmar ou a enriquecer, por fora, as antigas. A sua expressão pior é o concordismo, que consiste na infusão de múltiplos princípios novos no corpo do antigo sistema.

A terceira forma de neo-tomismo, que não visa espichar conclusões ou justapor contribuições discrepantes, 
distingue-se pelo propósito de "nourrir par le dedans ce vivant qu'est le système, en lui faisant assimiler toute la substante nutritive que les siècles ont depuis elaborée. Vetera novis augere: c'est la formule de Leon XIII". Fazer com Santo Tomás, em suma, o que êste fêz com o sistema de Aristóteles. (31)

Depois da explanação contida no presente trabalho, não resta dúvida que João Mendes Júnior corresponde mais, embora não integralmente, ̀̀ primeira categoria acima apontada. Daí as perguntas que formulei sôbre o possivel significado da "atualidade de seu pensamento"

20 - Múltiplas explicações poderiam ser tentadas, e a elas quero apenas fazer referência, como hipóteses de trabalho.

Em primeiro lugar, a presença atuante de João Mendes Júnior demonstra que entre nós não vinga apenas o filoneismo, o amor pelas coisas novas, a paixão pelas doutrinas mais recentes, mal de que padeceram Tobias Barreto e Sílvio Romero e que tem sido mais um "mal do Nordeste": em contraposição àquela tendência, afirma-se a virtude ou o vício (é claro que variam as perspectivas no uso do têrmo adequado. .) do misoneismo, mal de que padeceu João Mendes Júnior e que têm sido mais um "mal do Sul".

A instabilidade de nosso desenvolvimento no plano das idéias, - as quais não defluem de um diálogo travado originàriamente entre nós mesmos, mas provém da reprodução de diálogos ou polêmicas travados alhures, - explica a persistência de certos pensadores no ancoradouro do passado, o que é também uma forma de evasão no tempo, como outros se evadem mentalmente das circunstâncias a que pertencem, vivendo espiritualmente em Nova York ou em Paris, em Roma ou Berlim. Uma falta de

(56) Sertillanges - Saint Thomas d'Aquin, Paris, 1912, 2. a ed., vol. II, págs. 332 e segs. 
confiança na própria capacidade criadora, um receio, que só agora começa a ser vencido, de oferecer algo válido no mundo da especulação pura, - diria quase, um estranho "complexo de inferioridade", - projeta-nos para fora do espaço e do tempo, gerando filhos da mesma anciedade, aparentemente tão distantes uns dos outros, os filoneistas e os misoneistas. Une-os o mesmo mal da carência de historicidade autêntica, pois não basta o amor das coisas antigas para se ter senso histórico: o passado não deve ser algo de estático, que se contemple, projetado para fora de nós, mas é antes um momento em nosso projetar-se para o futuro.

Se pensarmos, por outro lado, que ainda não passamos pela crise fecunda e renovadora de uma Filosofia crítica; que o nosso "criticismo" já veio diluído em doutrinas inspiradas em A. Comte ou em Spencer; compreende-se não só a persistência da Escolástica ortodoxa parada no tempo, mas também a conversão em "escolasticismo formal" de outras tendências, como se deu com o positivismo de Miguel Lemos e Teixeira Mendes e tende a ser o drama de certos neo-positivistas só extrínsecamente revolucionários.

Por fim, não há que esquecer, no caso de João Mendes Júnior, o jogo floral dos "distínguos" de tanta significação nos círculos jurídicos pátrios, onde ainda prevalece o culto do Direito como interpretação e construção formal de preceitos, de longe em longe tocados por um sopro de indagação filosófica, apesar de possuirmos um cabedal de verdadeira Ciência, como a que nos vem de Teixeira de Freitas ou de Clovis Bevilaqua.

Quando pesar no espírito de nossos pensadores tôda a fôrça do presente, não como instante imediato è fugaz, mas como a concreção de nosso passado e de nosso futuro; quando vivermos realmente inseridos na problemática de nossas circunstâncias, natural e expontâneamente, sem sentirmos mais a necessidade de proclamá-lo a todo instante, quando houver essa atitude nova, saberemos conversar sôbre nós mesmos e entre nós mesmos, recebendo idéias $\epsilon \mathbf{S -}$ 
trangeiras como acolhemos uma visita que nos enriquece, mas não chega a privar-nos da intimidade de nosso lar.

21 - Há, porém, um outro motivo que explica a repercussão da doutrina do direito de nosso antigo ministro do Supremo Tribunal: é a brasilidade de seus ensinamentos, a vinculação de seus estudos a uma linha de continuidade luso-brasileira.

Digam o que disserem certos detratores, - em geral bacharéis desenganados ou marginais - é preciso reconhecer que a Ciência do Direito no Brasil já atingiu certo grau de maturidade, oferecendo um cabedal de experiências nossas, ligadas à tradição lusa. Se não há traços relevantes de uma Filosofia brasileira, como estilo ou maneira de filosofar, há inegàvelmente um Direito brasileiro, correspondente a certas constantes no nosso modo de colocar os problemas, constantes essas que se não deformaram em contato com as teorias européias ou as norte-americanas. Nêsse sentido, a obra de jurisconsulto de João Mendes Júnior representa um dos elementos mais significativos de nossa cultura jurídica, assinalada por um traço pragmático muito vivo, por um desejo de adequação das teorias às exigências mutáveis e conflitantes de uma sociedade sujeita a crises naturais de expansão e desenvolvimento.

Se Rui Barbosa, Clovis Bevilaqua, Pedro Lessa e João Monteiro, por exemplo, são juristas banhados de cultura jurídica universal (o último vaticinou mesmo o advento de uma "cosmópolis do Direito") nenhum dêles comprometeu o gênio próprio de nossas instituições fundamentais, e souberam introduzir inovações substanciais nos modelos em que se inspiraram.

Há, no entanto, uma outra corrente, mais numerosa, mais ligada ao processo de nossa formação político-jurídica, com representantes do porte de Teixeira de Freitas, Pimenta Bueno, Paula Batista e Lafayette. É nesta corrente que se situa a obra de João Mendes Júnior, a de mais pronunciado apêgo à tradição. 
Em Teixeira de Freitas é bem viva a presença de Savigny e da Escola Histórica, à cuja luz reelabora poderosamente o legado do Direito reínicola, dando-Ihe uma estrutura técnico-dogmática de tal ordem que é certamente com as suas obras fundamentais que se emancipa o Direito Brasileiro. Ainda é tarefa por fazer-se, à qual espero abalançar-me algum dia, se para tanto me sobrar engenho e arte, a de indagar dos pressupostos teoréticos da obra do jurisconsulto insígne, a-fim de deslindar o significado de Savigny e dos mestres da "Escola de Exegese" nos escritos do mais original dos nossos jurisconsultos. (57)

Nos trabalhos do paulista Pimenta Bueno, _ cuja alta projeção na Jurisprudência pátria não tem merecido mais carinhoso estudo de nossos conterrâneos - palpita tôda a problemática do Direito Público no meado da última centúria, e os problemas do Direito pátrio animam-se de um sentido de universalidade própria de um mestre de liberalismo.

Em Lafayette Rodrigues Perreira, não obstante a riqueza de sua formação tradicional, nota-se a absorção benéfica de influências estranhas à linha ibérica. Nos seus livros, as contribuições da Escola da Exegese ajustam-se tão bem ao rigorismo e à limpidez de sua linguagem científica, quanto se mostra a sua inteligência sensivel às cautelas de prudência e de "suspicácia" inspiradas num "kantismo" acomodado às teorias justanaturalistas. (58)

De Paula Batista pode-se dizer que soube fundir o velho e o novo em contribuições que se revestem de impressionante atualidade. As antecipações apontadas em sua teoria processualística talvez sejam o fruto da experiência original do Direito Iuso fecundada pelas lições hauridas na Jurisprudência de seu tempo. (59)

(57) A esta questão me ref́iro sumàriamente no citado trabalho sôbre a Doutrina de Kant no Brasil, págs. 71 e segs.

(58) V. Doutrina de Kant no Brasil.

(59) V. Alfredo Buzaid - Paula Batista, atualidades de um. velho processualista, São Paulo, 1950. 
João Mendes Júnior foi de todos o menos propenso a acolher as "novidade" do Direito alienígena, o que não signifiea tenha êle ignorado as grandes doutrinas de um século assinalado, - em confronto com o nosso, em que pese o vaticínio pessimista de Savigny, - por forte vocação pela Legislação e a Jurisprudência. Pode, pois, ser considerado um padrão de jurisconsulto tradicional, no fundo e na forma, um paradigma que, como tôdas as posições nìtidamente talhadas, há de suscitar aplausos e críticas apaixonadas. A sua obra só poderá, por isto mesmo, ser julgada serenamente se nos situarmos no plano de uma doutrina capaz de integrar, em nova síntese superadora, as exigências especulativas e práticas a que êle procurou atender, sem ter conseguido, a meu ver, resolver as aporias decorrentes de seu escolasticismo abstrato e de seu amor pelo empirismo fundamental dos praxistas. Todavia, o seu propósito de conciliar a teoria e a realizabilidade do Direito constitui uma diretriz segura para uma compreensão melhor da Ciência Jurídica.

Pena é que, após os contrastes filosófico juridicos, que deram sentido de participação às idéias universais e interêsse ideológico à geração de João Mendes Júnior e de Pedro Lessa, tenha havido um hiato na preocupação dos jurisconsultos de São Paulo pelas coisas da Filosofia, em parte devido ao declínio da inquietação positivista e evolucionista, que, não obstante suas deficiências especulativas, atuara em nosso meio jurídico como fermento benéfico, - e também pelo hábito que passou a imperar da repetição convencional dos esquêmas escolásticos que na obra de João Mendes Júnior tinham pelo menos a fôrça de uma convicção amadurecida na intencional "contemplação dos primeiros princípios".

São Paulo, Novembro de 1956. 